University of Nebraska - Lincoln

DigitalCommons@University of Nebraska - Lincoln

USDA National Wildlife Research Center - Staff

Publications

U.S. Department of Agriculture: Animal and Plant Health Inspection Service

April 2006

\title{
WEST NILE VIRUS IN NORTH AMERICAN BIRDS
}

Robert G. McLean

U.S. Department of Agriculture, Wildlife Services National Wildlife Research Center, Animal \& Plant Health Inspection Service

Follow this and additional works at: https://digitalcommons.unl.edu/icwdm_usdanwrc

Part of the Environmental Sciences Commons

McLean, Robert G., "WEST NILE VIRUS IN NORTH AMERICAN BIRDS" (2006). USDA National Wildlife Research Center - Staff Publications. 425.

https://digitalcommons.unl.edu/icwdm_usdanwrc/425

This Article is brought to you for free and open access by the U.S. Department of Agriculture: Animal and Plant Health Inspection Service at DigitalCommons@University of Nebraska - Lincoln. It has been accepted for inclusion in USDA National Wildlife Research Center - Staff Publications by an authorized administrator of DigitalCommons@University of Nebraska - Lincoln. 


\title{
CHAPTER 3
}

\section{WEST NILE VIRUS IN NORTH AMERICAN BIRDS}

\author{
Robert G. McLean ${ }^{1}$ \\ U.S. Department of Agriculture, Wildife Services National Wildlife Research Center, Animal \& Plant Health Inspection \\ Service, Fort Collins, Colorado 80521, USA
}

\begin{abstract}
Following the introduction of West Nile virus (WNV) into the United States, in New York City in 1999, from its historical range in the eastern hemisphere, this mosquitoborne virus caused an intense outbreak in local bird populations and a small epidemic in the associated human population. West Nile virus became established in this focal area, and in 2000 it spread north and south from there during the summer transmission season. The virus continued to expand during the next six years, ultimately affecting all the continental states and most of North America. The strain of WNV introduced was uncharacteristically virulent as a disease agent in native avian species in North America. Corvid species, particularly the American Crow (Corvus brachyrhynchos), were affected the most, and mortality in American Crows and other corvid species was used as a sensitive sentinel system to detect the presence and movement of the virus through a public-health-reporting and laboratory-testing national surveillance program. American Crows were also the earliest indicator of virus activity in most locations and a useful predictor of human cases. The temporal and spatial pattern and rapidity of the continental spread of WNV, as detected by the national surveillance system, matched the semiannual migratory movements of hundreds of millions of North American birds. Subsequent dissemination of the virus to Canada, the Caribbean, Mexico, and Central America fit this method of spread as well.
\end{abstract}

Nationwide bird mortality from WNV infections has been dramatic in North America during the past seven years, with $\sim 48,000$ dead birds of $>200$ species reported as WNV-positive. Experimental studies have elucidated the susceptibility and reservoir competence of a number of bird species. The actual effect of the mortality on bird populations is not known because of the insensitivity of national population-census data available on birds. Few regional declines in bird populations have been detected; however, effects of WNV on local populations of American Crow and Greater Sage-Grouse (Centrocercus urophasianus) has been observed in some localities. Geographic distribution of WNV transmission is not continuous across local landscapes, and unexposed birds of susceptible species can serve as a source to repopulate local affected areas when overall populations are high.

Bird infections and mortality from WNV peak during August-September, at the height of the mosquito-transmission period, but extend from April to November each year in some states. West Nile virus is able to persist through winter and reappear annually in spring in temperate regions of the continent, and the mechanisms responsible for this recrudescence are unique and largely unknown. Prevention of WNV focuses on mosquito control to suppress virus transmission, particularly during the summer amplification period, but other strategies, such as early targeted mosquito control and possibly wildlife vaccines, would be beneficial. Information from ecological studies and realistic mathematical models are needed for management of this disease. Received 6 June 2005, accepted 30 November 2005.

Resumen. - Después de la llegada del virus del Oeste del Nilo (VON) a los Estados Unidos, específicamente a la ciudad e Nueva Cork en 1999, causo un brote intenso en las poblaciones de aves locales y una pequeña epidemia en la población humana. El virus del Oeste del Nilo se estableció en esta área en particular, y en el año 2000 se extendió hacia el norte y sur durante el verano. El virus continúo extendiéndose por los siguientes seis años, para finalmente llegar a afectar todos los estados continentales y la mayoría de Norte América. La cepa introducida 
del virus del oeste del Nilo era inusitadamente virulenta como agente infeccioso en aves nativas de Norte América. Las especies mas afectadas fueron los córvidos, particularmente Corvus brachyrhynchos, y la mortalidad en esta especie y otras especies de córvidos fue usada como un sistema sensible de monitoreo para detectar la presencia y movimiento a través de un programa de vigilancia nacional de cobertura de salud publica y pruebas de laboratorio. Corvus brachyrhynchos fueron los primeros indicadores de la actividad infecciosa del virus en la mayoría de los sitios y fueron también el medio por los cuales se predijeron casos en humanos. Los patrones de espacio y tiempo así como la rapidez de la propagación continental del VON, de acuerdo a lo registrado por el sistema de vigilancia nacional, coincidió con los movimientos migratorios semianuales de cientos de millones de aves de Norte América. Las propagaciones subsiguientes del virus hacia Canadá, el Caribe, México y Centroamérica también siguieron el mismo patrón de propagación.

La mortalidad de aves a nivel nacional debido a las infecciones del VON ha sido verdaderamente dramática en Norteamérica durante los últimos siete años, donde aproximadamente 48,000 aves muertas pertenecientes a mas de 200 especies diferentes fueron reportadas VON positivas. Estudios experimentales han aclarado la susceptibilidad y la capacidad de reserva de un número de especies de aves. El efecto real de la mortalidad en las poblaciones de aves no se conoce debido a la insensibilidad de información disponible sobre censos poblaciones de aves a nivel nacional. Solo algunas disminuciones regionales en las poblaciones de aves han sido detectadas; sin embargo, efectos del VON en poblaciones locales de Corvus brachyrhynchos y de Centrocercus urophasianus han sido observados en algunas localidades. La transmisión de el VON no presenta un patrón de distribución geográfico continuo a lo largo de regiones locales, y aves no expuestas de especies susceptibles pueden servir como una fuente para repoblar áreas localmente afectadas cuando las poblaciones en general son altas.

Las infecciones y mortalidad en aves debido a el VON fueron mas altas durante los meses de Agosto y Septiembre, coincidiendo con la temporada de moscos transmisores, pero se extendió de Abril a Noviembre de cada año en algunos estados. El virus del Oeste del Nilo es capaz de persistir durante el invierno y reaparecer anualmente en primavera en regiones templadas del continente y los mecanismos responsables de esta extensión son únicos y ampliamente desconocidos. La prevención de el VON se basa en el control de moscos para evitar la transmisión del virus, especialmente durante el periodo de verano, aunque otras estrategias tales como el control temprano de los moscos y posibles vacunas para especies de fauna silvestres serian de gran beneficio. Las informaciones provenientes de estudios ecológicos y de modelos matemáticos reales son necesarias para el manejo de esta enfermedad.

THE SUDDEN INVASION of the United States by West Nile virus (WNV) in 1999 triggered an unexpected series of events that challenged our public health, domestic animal health, and wildlife health agencies. Here, I describe the changing events and unique characteristics of WNV after it entered these novel environments and infected naïve avian host populations in North America, and the evolving ecology of this new virus-host system as it spread across the continent.

The introduction of WNV into New York City in 1999 initiated an epizootic in the local bird populations, followed by a human epidemic in the area (Centers for Disease Control and Prevention [CDC] 1999). The epizootic resulted in a large number of bird deaths, predominantly of American Crows (Corvus brachyrhynchos) within the epicenter of the initial introduction site in Queens and of free-ranging American Crows and native and exotic captive birds at a zoo and wild-animal park in the nearby Bronx (Steele et al. 2000). The bird mortality occurred from August to November, peaking in September, and expanded from the central cluster of WNV-positive tested birds within New York City to a more than 160-km-wide area in 22 surrounding counties in New York, New Jersey, and Connecticut (Eidson et al. 2001a; Fig. 1). Reports of dead American Crows from the public corresponded to the outward expansion of WNV, which indicated that American Crows were valuable in detecting local transmission and were likely involved, along with other bird species, in the local expansion of WNV out of New York City. As a result, thousands of American Crows may have died from WNV infections during the first year (Eidson et al. 2001b).

West Nile virus (Flavivirus; Flaviviridae) is a mosquito-borne virus that has a historical range in Africa, the Middle East, Europe, and 


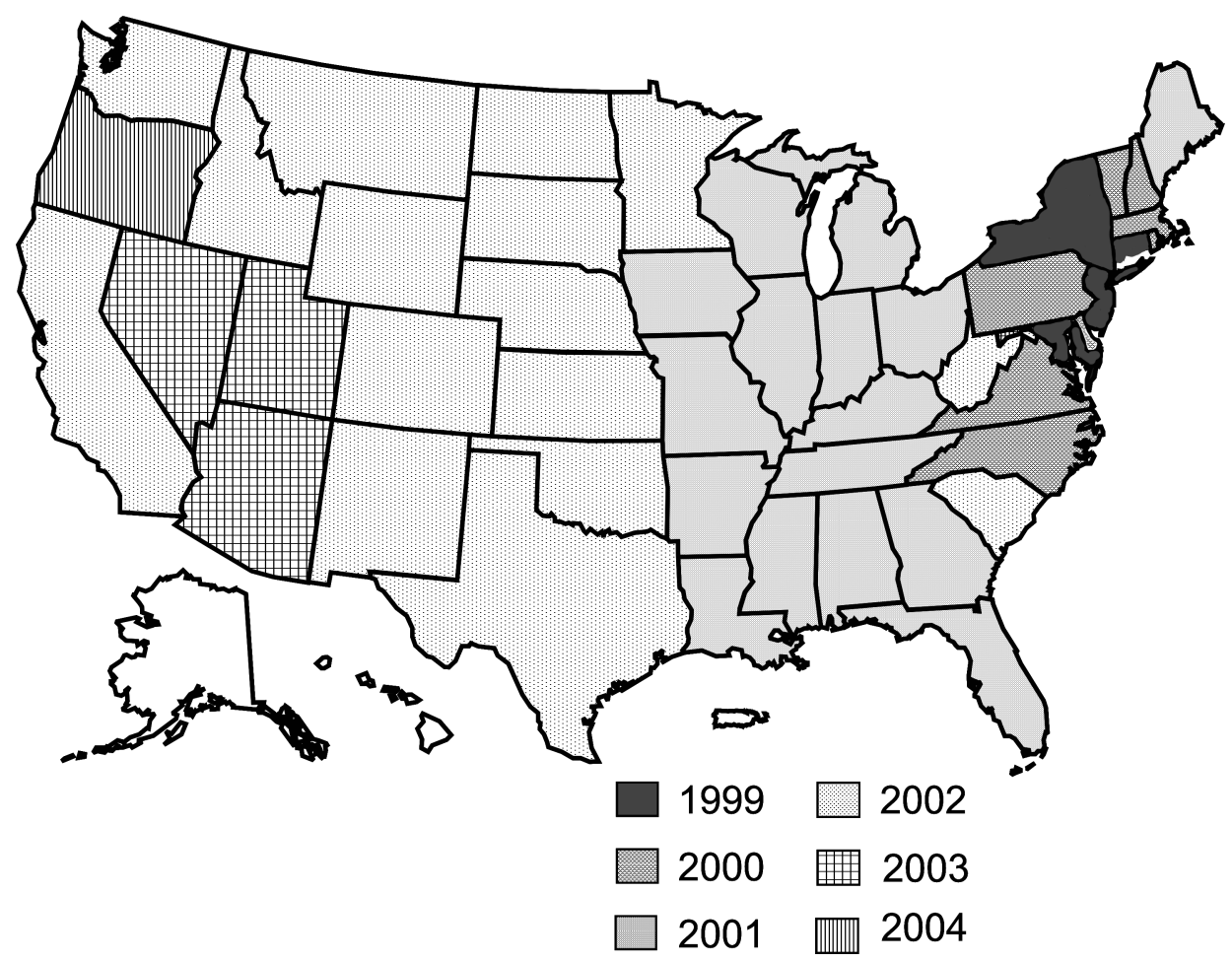

FIG. 1. States that reported positive tests for West Nile virus by year of first reporting, 1999-2004.

western Asia (Murgue et al. 2002). The virus was originally isolated in 1937 from a human patient in the West Nile region of Uganda (Smithburn et al. 1940). Birds are the primary hosts, and Culex mosquitoes the major vectors, though there have been isolations from mammals, reptiles and amphibians, other mosquitoes, and ticks (McLean et al. 2002). There are two separate genetic lineages of WNV that differ in their virulence and ability to produce disease (Petersen and Roehrig 2001). Lineage 2 strains are associated with a wide distribution of endemic transmission in Africa and are not known to cause significant human disease or mortality in birds (Malkinson and Banet 2002a). By contrast, lineage 1 strains occur throughout the geographic distribution of WNV and include strains that caused recent epidemics in humans and epizootics in horses (Equus caballus). The WNV strains circulating in nature within the historical range did not cause noticeable mortality in naturally exposed wild birds, including Hooded Crows (C. corone cornix) in Egypt (Work et al. 1955), until 1997-1998, when an apparently new WNV strain (Isr98) caused some mortality in domestic geese
(Swayne et al. 2001) and migrating White Storks (Ciconia ciconia; Malkinson et al. 2002b) in Israel. The WNV strain (NY99) introduced into the United States in 1999 was closely related to this Isr98 strain (Lanciotti et al. 1999) but appeared to be more virulent, especially to native species of Corvidae, and has become a significant cause of avian mortality in North America (Bernard et al. 2001, McLean 2002). The survival of this introduced virus in its new temperate environment and its subsequent spread and establishment in North America were unprecedented.

As WNV spread beyond New York City in 2000, expanded state surveillance to monitor WNV activity and to detect dissemination of the virus was established, and many states used American Crow mortality to assess WNV activity (CDC 2000). The reporting and testing of dead American Crows became an ideal sentinel system for public health surveillance (Eidson et al. 2001a) because of their high susceptibility to WNV infection; their wide distribution in rural, suburban, and urban habitats; and their being easily noticed and reported by the public when sick or dead. Other corvid species (e.g. 
jays and magpies) that were equally susceptible were also effective sentinels in other states. Use of dead birds for public health surveillance of WNV was a new and unique method, because other avian diseases of public health importance in North America, such as St. Louis encephalitis (SLE; Flavivirus, Flaviviridae), eastern equine encephalitis (EEE; Alphavirus, Togaviridae), and western equine encephalitis (WEE; Alphavirus), do not produce significant bird mortality in native species. Other generally less-sensitive and less-effective surveillance methods must be used for these viruses (Moore et al. 1993).

\section{Surveillance AND EXPANSION of West Nile Virus}

After WNV entered New York City in 1999, the virus was initially confined to the northeastern United States during 1999-2000, but during the next four years, WNV spread throughout North America, moving $\sim 3,000$ miles to the west, $\sim 500$ miles north, and $\sim 3,000$ miles south, and has affected all 48 continental states, seven provinces in Canada, parts of Mexico, numerous islands in the Caribbean, and Central America (Hayes 2004, Mendez-Galvan 2004). A total of 47,923 birds from 294 species of native and exotic, free-ranging and captive species has been reported infected with
WNV in the United States through the national surveillance system during 1999-2004 (Smith 2005). American Crows (26,466; 55\% of total) were the dominant species found positive for the first three years; Blue Jays (Cyanocitta cristata) and then Black-billed Magpies (Pica pica) and Yellowbilled Magpies ( $P$. nuttalli) became prominent as the virus moved westward from the original introduction site. The annual public health reporting of WNV in birds during its expansion in the United States and its sequential movement across the continent will be described below.

\section{United States}

During the initial bird surveillance in 1999 (Eidson et al. 2001a, b), 17,339 dead birds were reported by the public, 5,697 (33\%) of which were American Crows; 295 of 671 (44\%) dead birds collected and tested were laboratory-confirmed WNV-positive, and 269 (89\%) of these positive birds were American Crows (Fig. 2). After the initial expansion of WNV activity in the New York City area in 1999, the virus survived through the temperate winter and reappeared within the epicenter focal area in May 2000 (CDC 2001). The multistate surveillance system established to track the movement of the virus (CDC 2000) consisted of enhanced passive reporting of human

\section{Other birds 圆 Corvids $⿴$ Crows 圈 Total birds}

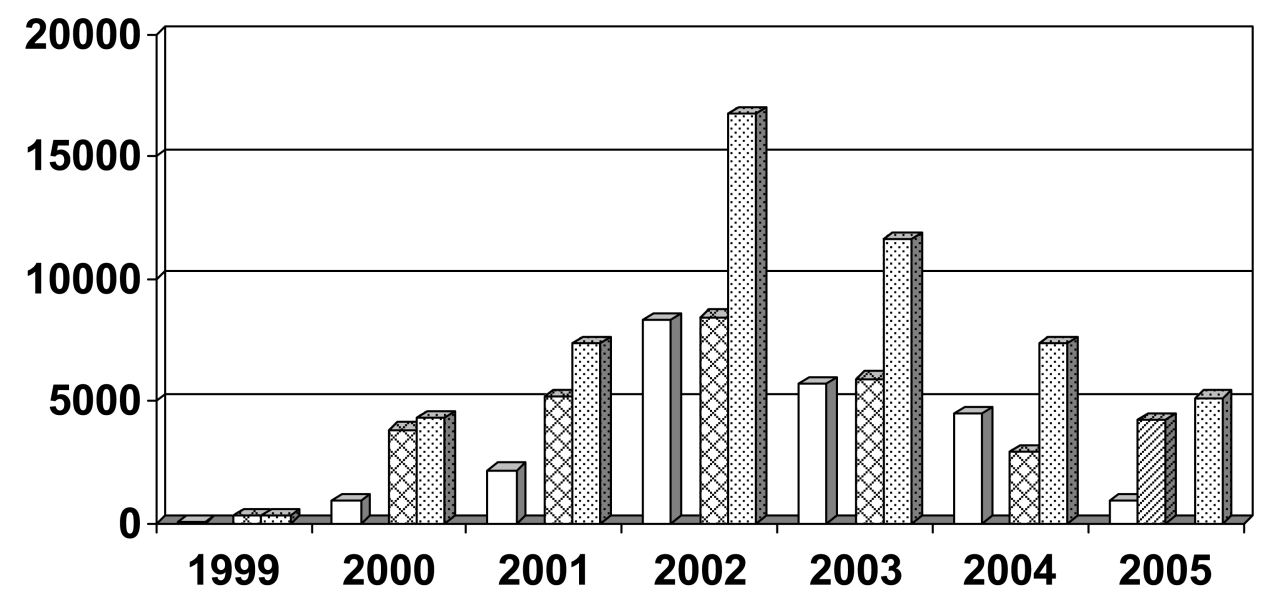

Fig. 2. Numbers of birds reported positive for West Nile virus in the United States, 1999-2005. The 2005 data are provisional and incomplete. Stippling shows the total number of birds of all species, cross hatching the number of American Crows, diagonal lines the number of corvids (for 2005 only), and solid white the number of birds of all other species (Eidson et al. 2001a, Marfin et al. 2001, Campbell 2003, Hayes 2004, Smith 2005). 
and equine clinical cases; mosquito monitoring, collection, and virus testing; regular sampling and testing of blood from captive sentinel birds to detect antibody conversion; and dead-bird reporting and testing for WNV. Surveillance data were accumulated within each state, submitted to a national surveillance database, ArboNet at CDC, and verified and updated weekly (Marfin et al. 2001). The type and extent of dead-bird surveillance varied among states in 2000. For example, New York tested any bird species submitted (Bernard et al. 2001), whereas other states, like Connecticut, tested only American Crows (Hadler et al. 2001).

Following the initial reappearance of the virus in 2000 in the New York City area, WNV activity, as monitored by the surveillance system, was detected northward and northwest from the New York City area into upstate New York and the New England states during the early- to midsummer transmission season, and subsequently southward through the mid-Atlantic states to North Carolina by the fall, both reflecting the movement of migratory birds. The 2000 expansion included 12 northeastern states and the District of Columbia; 12,961 dead birds were submitted for WNV testing, with 4,305 (33.3\%) found infected (Marfin et al. 2001). American Crows made up 58\% of the birds tested and $89 \%$ of the WNV-positive birds (Fig. 2); $50.4 \%$ of the 7,580 American Crows tested were infected. In New York, $68 \%$ of the positive birds were crows (Corvus spp.), and the remaining 32\% of the positives were among 59 other bird species (Bernard et al. 2001). Of the 1,732 crows (Corvus spp.) tested in New York, 47\% were WNV-infected, compared with $70 \%$ of 1,574 crows (Corvus spp.) tested in Connecticut (Hadler et al. 2001, Beckwith et al. 2002). However, the percentage of WNV-positive crows (Corvus spp.) in the state of New York varied, with $67 \%$ positive in the 1999 epicenter area around New York City, which was similar to the $70 \%$ in southern Connecticut, also from the 1999 epicenter; but only $23 \%$ of crows (Corvus spp.) were positive in upstate New York, where there was no known WNV activity before 2000 (Table 1). The single positive American Crow detected in North Carolina in fall 2000 was an indication of a late-season southward spread and local establishment of WNV, probably by fall-migrating birds but not American Crows. Following the 12-state expansion of WNV activity in the northeastern United States in 2000, the
Table 1. Number of dead crows (Corvus spp.) that were submitted and tested positive for West Nile virus in two epizootic states and for the United States, 2000 (Bernard et al. 2001, Hadler et al. 2001, Marfin et al. 2001).

\begin{tabular}{|c|c|c|c|}
\hline Location & $\begin{array}{c}\text { Number } \\
\text { tested }\end{array}$ & $\begin{array}{l}\text { Number } \\
\text { positive }\end{array}$ & $\begin{array}{c}\text { Percentage } \\
\text { positive }\end{array}$ \\
\hline New York State & 1,732 & 814 & 47 \\
\hline $\begin{array}{l}\text { New York City } \\
\text { area (epicenter) }\end{array}$ & - & - & 67 \\
\hline $\begin{array}{l}\text { Upstate (non- } \\
\text { epicenter) }\end{array}$ & - & - & 23 \\
\hline $\begin{array}{l}\text { Connecticut } \\
\text { (epicenter) }\end{array}$ & 1,574 & 1,095 & 70 \\
\hline United States & 7,579 & 3,823 & 50 \\
\hline
\end{tabular}

virus again survived through the dormant winter season and reappeared in American Crows at individual sites in five separate states in the northeast in late April and early May of 2001, which indicates an efficient local overwintering of the virus. A new focus of WNV was detected in northern Florida in June 2001, $>600 \mathrm{~km}$ south of the lone 2000 WNV-positive American Crow in North Carolina and $>950 \mathrm{~km}$ south of the 2000 epizootic area, and the focus began to expand quickly in all directions (Blackmore et al. 2003). This WNV focus was probably started initially during the fall of 2000 by migratory birds that became infected in the northeast and carried the virus south with them during their fall migration to and through Florida. The seeding of virus and establishment of WNV transmission at this Florida site were certainly influenced by the extended period of continuous mosquito activity that occurs during the winter months in the warmer Gulf Coast areas of the southeastern states. Transmission of WNV in the birdmosquito cycle in northern Florida remained below surveillance detection until amplification of transmission was sufficient in June for dead crows (Corvus spp.) to be observed and submitted for WNV testing from this rural area (CDC 2001). Given that mosquito transmission within this WNV focus was likely occurring weeks to months before the detection of WNV-positive dead crows (Corvus spp.) in June (Godsey et al. 2005), migrating birds could have become infected while traveling north through the area in April and May and carried WNV to northern locations, including to some midwestern states.

In 2001, WNV expanded from the northeast and from the new focus in northern Florida 
to eventually encompass 27 states (Fig. 1), including south to the Florida Keys (Blackmore et al. 2003) and north to the southern tip of Ontario, by the end of the transmission season in November. Detection of this expansion was again led by dead-crow surveillance and resulted in 7,338 reported WNV-positive birds (5,161 American Crows; 70\%) for the United States (Fig. 2) and 121 WNV-positive birds (100 American Crows; 83\%) for Canada (Health Canada 2005). The virus was detected in the midwestern states of Ohio, Michigan, Wisconsin, Illinois, and Indiana starting in July and August and expanded in those states throughout the remainder of the transmission season (CDC 2001). After the beginning of fall bird migration to the south in August from these infected sites in northern states, locations in states along the Mississippi Flyway began detecting WNV-positive dead birds, until all the states, except Minnesota, on both sides of the Mississippi River south to Louisiana reported positive birds, indicating the southward movement of WNV by migratory birds. Some of the reporting sites were in cities on the river, like St. Louis, Missouri, and Memphis, Tennessee (CDC 2001, U.S. Geological Survey [USGS] 2005). Memphis first detected WNV in September and then reported 44 positive birds during September and October. Positive birds were detected during the early months of 2002 in Louisiana and Florida, indicating continuous transmission in the Gulf Coast states; and again, WNV-positive American Crows were found by April in five states in the northeastern United States (CDC 2002a). This local persistence of WNV in Gulf Coast states through the temperate winters provides a continuing source of virus for early-season transmission and subsequent amplification in a number of sites and gives a jumpstart to the summer transmission season. By June 2002, WNV was detected in birds in 24 states, including the newly infected state of Texas. Soon after, WNV was detected 2,000 km to the north, in North Dakota and Minnesota and, in July, along the Canadian border in those states; this was further evidence for northward movement of the virus in spring by migratory birds in the Mississippi and Central flyways.

During the summer 2002 transmission season, the virus expanded throughout the eastern and central states to affect 44 states and 5 Canadian provinces, and was detected in Mexico and on several Caribbean islands. This represents the largest geographic expansion and largest increase in human, equine, and avian cases (Fig. 1) of WNV. The greatest intensity of transmission occurred in the central United States, from Louisiana in the south to Nebraska and South Dakota to the west and Illinois, Indiana, and Ohio to the east. In Canada, WNV expanded throughout the southern health units in Ontario and eastward to Quebec and Nova Scotia, as well as westward to the plains provinces of Manitoba and Saskatchewan (Health Canada 2005).

In 2002, the United States reported 15,745 WNV-positive birds (8,420 American Crows; $53 \%$ ) (Fig. 2) in 42 states; Canada reported 563 WNV-positive birds of 3,658 tested (15\%), and $87 \%$ of the positive birds were American Crows (Health Canada 2005). The virus was also detected in Washington in American Crows and equines at some distance from the leading front, likely introduced and seeded by infected birds migrating westward to Washington during late summer from the Great Plains in the northern United States or southern Canada. The virus seeding was apparently not successful, because WNV was not detected in Washington again during the next two years, despite continuous testing (Smith 2005).

The geographic expansion of WNV in North America continued westward in 2003 with a smaller geographic expansion than in 2002, but with increased virus activity, producing the largest human outbreak $(9,100$ cases) of this disease in history (Hayes et al. 2004). The greatest intensity of WNV transmission occurred in a multistate region from west Texas north through the Great Plains states and into Canadian provinces; Colorado reported the most human cases $(2,947)$, though the highest incidence per 1 million population occurred in Louisiana, Nebraska, and South Dakota. The weather pattern of wet spring and hot summer in Colorado in 2003 (the same weather pattern that occurred in New York City in 1999 during the introduction of WNV) was ideal for the production of efficient vector mosquitoes ( $>5 \times$ the average annual number of adult mosquitoes were captured in 2003 compared with the previous five years) and for amplification of WNV transmission (Pape 2004). In addition, a resurgence of WNV activity was seen along the eastern coastal states, where $4 \times$ as many WNVpositive dead birds were reported per area as in the central and western states in 2003 (Hayes 
2004). The east coast had previously experienced epizootic transmission during 1999-2001, and the central states in 2002-2003; this indicates that WNV does not necessarily disappear after the epizootic front moves through a region. The virus appeared in and spread through southern Arizona into southern California, possibly entering from the south by migratory birds via the Pacific Flyway from Mexico. In 2003, the United States reported 11,597 WNV-positive birds, including 5,800 American Crows (50\% of positive birds) and 3,532 Blue Jays (30\%) in 46 states (Fig. 1 and Table 2). A small geographic expansion occurred in Canada also, with the addition of two new provinces: New Brunswick in the east and Alberta in the west. However, Canada reported a significant increase in WNV-positive birds $(1,632)$ in 2003 (Health Canada 2005).

The transmission season in 2004 was quite different from previous years in the states east of the Rocky Mountains, possibly because of weather conditions, with significantly fewer reports of WNV cases in humans and animals (Fig. 1 and Table 2). In contrast to the reduced WNV activity in the eastern states, Arizona and California were more typical of the epizootic activity that followed the introduction and establishment of WNV in new states during the previous year (2003). The 2004 virus activity was intense in the Phoenix metropolitan area in Arizona, and surveillance was different from that

TABLE 2. Species most frequently reported as West Nile virus (WNV) mortalities in the United States, 2003-2004 (Hayes 2004, Smith 2005). Percentages of total dead birds are given in parentheses.

\begin{tabular}{|c|c|c|}
\hline Species & $\begin{array}{c}\text { Number of } \\
\text { WNV-positive } \\
\text { birds } 2003\end{array}$ & $\begin{array}{c}\text { Number of } \\
\text { WNV-positive } \\
\text { birds } 2004\end{array}$ \\
\hline American Crow & $5,800(50 \%)$ & $2,879(39 \%)$ \\
\hline Blue Jay & $3,532(30 \%)$ & $1,826(25 \%)$ \\
\hline Western Scrub-Jay a & - & $626(9 \%)$ \\
\hline Black-billed Magpie & $319(3 \%)$ & - \\
\hline Yellow-billed Magpie ${ }^{\text {b }}$ & - & $304(4 \%)$ \\
\hline House Sparrow & $241(2 \%)$ & $282(4 \%)$ \\
\hline Northern Cardinal & $175(2 \%)$ & $115(2 \%)$ \\
\hline Fish Crow & $100(1 \%)$ & - \\
\hline Common Grackle & $91(1 \%)$ & - \\
\hline Red-tailed Hawk & $90(1 \%)$ & - \\
\hline Steller's Jay ${ }^{c}$ & - & $73(1 \%)$ \\
\hline American White Pelican & - & $72(1 \%)$ \\
\hline
\end{tabular}

in other states, in that dead-bird surveillance was not effective in detecting WNV and evaluating risks, partly because there were few highly susceptible bird species like corvids present in that area (Levy 2005). However, an outbreak of WNV with 391 human cases still occurred without the presence of many corvids. Of the 730 dead birds tested, 98 (13\%) were WNV-positive, including $31 \%$ unspecified sparrows, $18 \%$ birds of prey (Accipitridae, Falconidae, and Strigidae), and 14\% corvids. In the year following the 2003 introduction of WNV into California, WNV-positive dead birds were first detected in southern California on 24 February 2004, seven weeks before any other surveillance event and 11 weeks before the first human case (Kramer 2005). In April, virus activity began to amplify and expand in southern California and spread northward; WNV was detected in central California in May, in northern California in June, and throughout the state by September. Migrating birds were likely responsible for moving WNV northward in the spring from the Los Angeles area and seeding the virus into new areas, where it became established and amplified enough to be subsequently detected by the surveillance reporting system. Dead-bird surveillance in California efficiently detected the appearance and intensity of WNV transmission. Dead-birds testing was the only surveillance method that detected WNV in all 58 of the positive counties, was the earliest indicator of WNV activity in 53 (91\%) counties, and was the only evidence of WNV in 22 counties (Kramer 2005). California reported $44 \%(3,232)$ of the total WNV positive dead birds for the United States $(7,331)$ in 2004, compared with $0.8 \%$ in 2003 (Table 3). The dramatic increase in California in the number of dead birds and counties reported WNV-positive occurred during a decrease throughout the rest of the United States in 2004.

In contrast to epidemic conditions in the western United States, WNV activity in areas east of the Rocky Mountains was reported to be significantly less in 2004 (CDC 2004) than in 2003, likely because of unfavorable weather for WNV transmission. Climatic data for 2004 (National Oceanic Atmospheric Administration 2005) showed a significantly cooler and wetter summer, particularly compared with 2003, in the eastern region of the United States, whereas weather in the western region-including Arizona and California, where there was increased WNV activity-did not change from 
TABLE 3. Number of birds reported positive for West Nile virus (WNV) and percentage of corvids reported in California compared with the United States (USA, 2003-2004; Kramer 2005, Smith 2005).

\begin{tabular}{lccrrrr}
\hline \hline Surveillance activity & $\begin{array}{c}\text { California } \\
\text { Reported dead birds }\end{array}$ & $\begin{array}{c}\text { USA } \\
(\%)\end{array}$ & $\begin{array}{r}\text { USA } \\
2003\end{array}$ & $\begin{array}{r}\text { California } \\
2004\end{array}$ & $\begin{array}{r}\text { USA } \\
(\%)\end{array}$ & $\begin{array}{r}\text { USA } \\
\text { Corvids (\%) }\end{array}$ \\
WNV-positive counties & 96 & 0.8 & 11,597 & 3,232 & 44 & 7,331 \\
\hline
\end{tabular}

the previous five years. A combination of a wet and cool summer along with other factors can greatly reduce mosquito production and activity, lengthen the extrinsic incubation period of the virus in the vector, and affect reproduction and populations of insect-eating birds, all of which could reduce WNV transmission and lower the number of infected birds, equines, and humans in the temperate areas of the eastern United States. However, reduced WNV transmission in southeastern states such as Florida in 2004 was attributable to summer drought (Shaman and Day 2005).

During 2005, WNV activity was reported in all 48 continental states, with human cases reported in 42 states, WNV-positive mosquitoes in 43 states, and dead wild birds in 45 states (CDC 2005a). There were 2,653 human cases, 11,095 WNV-positive mosquito pools, and 5,129 dead birds reported as of 11 November 11 2005; $4,227(82 \%)$ of the reported birds were corvids (Fig. 2). There was a similar number of human cases and dead wild birds reported in 2005 as in 2004, and California again in 2005 reported the most WNV activity in the country: $32 \%$ (840) of the human cases and $58 \%(2,986)$ of the reported dead birds (California Department of Health Services 2005). However, a few states had a resurgence of human cases in 2005, for example, Illinois (241) and South Dakota (235).

\section{Other Countries in the Western Hemisphere}

Following the expansion of WNV in the northeastern United States in 1999-2000, the virus was transported out of the country in 2001-2004, both northward and southward, likely by migratory birds. Before the virus arrived in Canada in 2001, the Canadians developed a national WNV surveillance plan similar to the surveillance approach in the United States and implemented a dead-bird surveillance program concentrating on corvid testing. During the four years that WNV was active in Canada, 2001-2005, virus activity was first detected in Ontario and expanded in both directions to 7 of 10 provinces from Nova Scotia on the Atlantic coast to Alberta in the west (Health Canada 2005). There were 2,292 human cases reported during 2002-2005, and dead-bird surveillance found that 3,179 of 27,779 birds tested $(11.4 \%)$ during the past five years (as of 29 October 2005) were WNVpositive, mostly American Crows. As in the United States, there was a decline in WNV activity throughout Canada in 2004, following the peak year of activity in 2003.

The southward dissemination of WNV was first detected in the Caribbean in 2001 with a human case on the Cayman Islands (CDC 2001), and then WNV-antibody-positive resident birds were found in Jamaica (Dupuis et al. 2003) and the Dominican Republic (O. Komar et al. 2003) in 2002. Antibody prevalences in resident bird species on Jamaica (17 of $348 ; 5 \%$ ) and the Dominican Republic (5 of 118; 4\%) indicated establishment of local transmission on these Caribbean islands after the introduction of WNV by migratory birds from the United States. Antibody-positive equines were discovered in Puerto Rico in 2004 (CDC 2004). The first known WNV activity in Mexico was detected in seropositive equines in northern Mexico (Blitvich et al. 2003, Estrada-Franco et al. 2003) and in three other Mexican states along the Caribbean coast, including Yucatan, starting in July 2002 (Estrada-Franco et al. 2003). The first isolation of WNV was from a captive Common Raven (Corvus corax) in southern Mexico in the state of Tabasco in 2002 (Estrada-Franco et al. 2003). By 2003, WNV was active in 24 states, with six human cases and 2,630 seropositive equines (Mendez-Galvan 2004). Of 18,099 samples from birds, 10 were WNV-positive by reverse-transcription polymerase chain reaction (RT-PCR), including three from dead birds, and 
147 birds from 50 species were seropositive. The virus reached Colombia by fall 2004, as detected by WNV antibody in $9 \%$ of 130 equines tested from 10 different premises (Mattar et al. 2005).

Virus-positive American Crows were generally the first indication of WNV in an area and were the earliest positive seasonal surveillance event, 4-8 weeks before any other surveillance information. In 2002, detection of WNV-positive dead birds was the first surveillance event reported in $72 \%$ of positive counties where human cases were later found ( $\mathrm{O}^{\prime}$ Leary et al. 2004), and finding a WNV-positive bird before 1 August was a good predictor of subsequent human cases (Guptill et al. 2003). This predictive dead-bird surveillance was a valuable tool for public health agencies, even though it did not function in Arizona in 2004, but it was even more effective in California in 2003-2004 than previously reported for other states (Kramer 2005). Alternative wild-bird surveillance methods that have been used effectively for SLE and WEE viruses (Moore et al. 1993) could be employed where dead-bird surveillance is ineffective or unused. Live-bird sampling would also provide additional information on WNV exposure and antibody rates in wild bird populations (Ringia et al. 2004).

The temporal and spatial patterns of WNV spread described above-monthly from locale to locale and annually from state to statedepended on optimal conditions for local mosquito-bird transmission; on local, regional, and migratory bird movements; and on climatic conditions suitable for virus transmission. As WNV eventually moved into warm climates in the southern and southwestern states during 2001-2004, it became permanently established in states such as Florida, Louisiana, Texas, and California, where mosquitoes are continuously active and sustain year-round transmission to birds (Tesh et. al. 2004, Kramer 2005). These states may serve as annual sources of WNV for migratory birds that move through those states, where they can become infected and then introduce or reintroduce the virus to northern states in the spring (Godsey et al. 2005) or to locations south of the United States in the fall (Blitvich et al. 2003, Dupuis et al. 2003, O. Komar et al. 2003). The virus has become diffused throughout the continent and well established in transmission foci and now exists in an endemic (enzootic) state that will likely persist.

\section{Avian Mortality from West Nile Virus}

Information on morbidity and mortality of birds caused by WNV is obtained from surveillance reporting data, from captive and freeranging field studies, and from experimental infection studies. National surveillance data collected by all 48 continental states and the District of Columbia and compiled in the ArboNet database during the period 1999-2004 reported that 47,923 dead birds of 294 native and exotic species from 57 families and 24 orders tested positive for WNV (CDC 2005b, Smith 2005). These data indicate the broad host species susceptibility to this new virus and the potential national threat to the avifauna of North America. The most complete data for evaluating bird mortality from WNV are for the American Crows, because this species was significantly affected by WNV during its six-year presence in North America from 1999 to 2004 (McLean 2004). Corvid mortality data were collected continuously during that period, because they were used for public health surveillance to detect and track this disease during its establishment and subsequent expansion on the continent. During the six years of dead-bird surveillance, American Crows accounted for $55 \%$ of the overall reported bird mortality (Smith 2005), but the annual proportion of reported WNV mortality in American Crows declined over the years, from $93 \%$ in 1999 to $39 \%$ in 2004 , as other corvid species became more affected (Fig. 2 and Table 2).

Mortality from WNV infection has been observed and documented in some captive and free-ranging avian species (Table 4). High morbidity and mortality occurred from WNV in the captive avian collection of the Bronx Zoo-Wildlife Conservation Park in New York City during the original outbreak in late summer and early fall 1999 (Ludwig et al. 2002). Of the 368 birds of 124 species tested, 125 (34\%) were WNV-antibodypositive indicating infection; 27 (22\%) of the 125 infected birds developed disease; and 19 (70\% fatality rate) of the 27 birds that became ill died. The fatality rates varied from $50 \%$ to $100 \%$ for bird species in various families. An outbreak of WNV within a captive colony of North American owls in 2002 in Ontario caused varying mortality, from 0 to $100 \%$ among different groups of owls (Gancz et al. 2004). Overall, $84 \%$ of the owls from 17 species were infected with WNV, and $43 \%$ died; $76 \%$ of the 91 survivors were 
TABLE 4. Estimated mortality from West Nile virus in local populations of various bird species (Caffrey et al. 2003, Yaremych et al. 2003, Gancz et al. 2004, Naugle et al. 2004, Rocke et al. 2005).

\begin{tabular}{|c|c|c|}
\hline Species (location) & $\begin{array}{l}\text { Number } \\
\text { of birds } \\
\text { observed- } \\
\text { tagged }\end{array}$ & $\begin{array}{l}\text { Mortality } \\
(\%)\end{array}$ \\
\hline American Crow (New York) & 68 & $37 \%$ \\
\hline American Crow (Illinois) ${ }^{a}$ & 28 & $68 \%$ \\
\hline American Crow (Oklahoma) & 78 & $65 \%$ \\
\hline $\begin{array}{l}\text { Greater Sage-Grouse (Wyoming, } \\
\text { Montana, Alberta) }^{a}\end{array}$ & 22 & $82 \%$ \\
\hline $\begin{array}{l}\text { American White Pelican } \\
\text { (North Dakota) }\end{array}$ & $10,000+$ & $95 \%$ \\
\hline $\begin{array}{l}\text { Captive owls (Canada): } \\
17 \text { species }^{\text {a }}\end{array}$ & 235 & $43 \%$ \\
\hline $\begin{array}{l}\text { Captive owls (Canada): } \\
3 \text { species }^{\text {a }}\end{array}$ & 73 & $97 \%$ \\
\hline
\end{tabular}

antibody-positive. Mortality among the owl species was variable, with the highest mortality rate $(>90 \%)$ in species with a northern native breeding-range and the lowest $(0 \%)$ in species with a southern breeding range. This information suggests that some populations of native owl species may be at risk from WNV.

Studies of local American Crow populations affected by WNV in 2002 showed an overall estimated mortality rate from the virus of $43 \%$ of 216 birds observed in three states (Table 4). The highest mortality rate occurred in central Illinois, where $68 \%$ of 28 radiotagged American Crows died from confirmed WNV infection during the 2002 summer transmission season (Yaremych et al. 2003). Confirmed and estimated American Crow mortality from WNV infection in a local New York American Crow population was 37\% of 68 birds (Caffrey et al. 2003), and estimated mortality in an Oklahoma population was $~ 40 \%$ of 120 American Crows in 2002 (Caffrey et al. 2003). An estimated $65 \%$ of 78 American Crows in this Oklahoma study population died from WNV infection in 2003 (Caffrey et al. 2005). There was no apparent gender-specific mortality in American Crows infected with WNV (Yaremych et al. 2004). Further evidence of the high mortality rate in American Crows from the virulent NY99 virus strain is the low WNV antibody prevalence detected in free-ranging populations exposed to the virus, which indicates low survival from WNV infection. Sampling of free-ranging American Crows in WNV-affected
Table 5. Prevalence of West Nile virus (WNV) antibody in American Crow populations exposed to WNV transmission in the United States, 19992002, compared with prevalence of WNV antibody in Hooded Crow populations in Egypt in the 1950s (Work et al. 1955, Jozan et al. 2003, Yaremych et al. 2003, R. McLean unpubl. data).

\begin{tabular}{|c|c|c|}
\hline Species & $\begin{array}{l}\text { Number } \\
\text { of birds } \\
\text { sampled }\end{array}$ & $\begin{array}{c}\text { Antibody } \\
\text { prevalence (\%) }\end{array}$ \\
\hline \multicolumn{3}{|c|}{$\begin{array}{l}\text { Epidemic status in United States, 1999-2002 } \\
\text { (American Crows) }\end{array}$} \\
\hline New York City area, 1999 & 175 & 1.1 \\
\hline New Jersey, 2001 & 78 & 5.0 \\
\hline Central Illinois, 2002 & 156 & 3.2 \\
\hline \multicolumn{3}{|c|}{ Endemic status in Egypt, 1950s (Hooded Crows) } \\
\hline Nonendemic & 64 & 3.0 \\
\hline Transitional & 102 & 31.0 \\
\hline Endemic & 124 & 77.0 \\
\hline
\end{tabular}

areas in the United States during epizootic transmission from 1999 to 2002 found low antibody prevalences ranging from $1.1 \%$ to $5.0 \%$ (Jozan et al. 2003, Yaremych et al. 2003, R. McLean et al. unpubl. data). By contrast, Carrion Crow populations in areas of Egypt in the 1950s (Work et al. 1955) that had varying degrees of endemic (enzootic) transmission of a less-virulent WNV strain had much higher antibody prevalences (Table 5). These high antibody prevalences in Egypt indicate that avian hosts survived WNV infection with very low mortality from this particular WNV strain.

At wildlife refuges in seven north-central states during 2002-2003, there were 11 die-offs of American White Pelicans (Pelecanus erythrorhynchos) from WNV (10 to 2,864 birds in each case, for a total of 9,322 birds; Rocke et al. 2005). About 95\% mortality was observed among the 10,000+ nestlings at a breeding colony in North Dakota in 2003; however, only carcasses submitted toward the end of the mortality event were tested and confirmed WNV-positive. Increased susceptibility of juvenile American White Pelicans to WNV and the cause of this proposed susceptibility remain to be determined; however, population effects from WNV must be considered.

Mortality of Greater Sage-Grouse (Centrocercus urophasianus, a declining and threatened species in western North America) caused by WNV was documented in free-ranging populations in Montana, Wyoming, and Alberta in 2003 (Naugle et al. 2004). Of 22 radiomarked females from four 
study sites that could be tested, 18 (82\%) died from WNV infection. In addition, serum collected from 112 Greater Sage-Grouse from those areas after the outbreaks were all antibody-negative, which suggests a low survival rate following WNV infection. Experimental studies confirmed the high susceptibility and mortality in Greater Sage-Grouse from WNV infection: 100\% mortality in second-year birds, with a 3.7-day mean survival time (L. Clark et al. unpubl. data).

Natural WNV infections in birds provide important information about the natural history and epizootiology of virus-vector-host relationships, but do not provide definitive information about the responses of the host and vector species to virus infection. Experimental infection studies were necessary to determine the specific mortality rate (actually, fatality rate; i.e. number of those infected that die) in birds and their susceptibility to and reservoir competence for WNV. Fatality from WNV infection for American Crows was $100 \%$ in three separate laboratory experiments (McLean et al. 2001, N. Komar et al. 2003, Brault et al. 2004), and fatality rates varied in small numbers of other species: $100 \%$ in Black-billed Magpies (Pica hudsonia), $100 \%$ in Ring-billed Gulls (Larus delawarensis), $100 \%$ in House Finches (Carpodacus mexicanus), $75 \%$ in Blue Jays, $55 \%$ in Fish Crows (Corvus ossifragus), $50 \%$ in House Sparrows (Passer domesticus), and 33\% in Common Grackles (Quiscalus quiscula) (Table 6). The differences in WNV fatality rates among bird species (e.g. between American and Fish crows in these studies) suggest genetic influences on susceptibility to WNV. However, the differences between the high fatality rates in American Crows from the virulent WNV (NY99) strain

TABLE 6. Mortality of select avian species following experimental infection with West Nile virus (from Komer et al. 2003).

\begin{tabular}{lcc}
\hline Avian species & $\begin{array}{c}\text { Number } \\
\text { infected }\end{array}$ & $\begin{array}{c}\text { Mortality } \\
(\%)\end{array}$ \\
\hline American Crow & 8 & $100 \%$ \\
Black-billed Magpie & 3 & $100 \%$ \\
Ring-billed Gull & 2 & $100 \%$ \\
House Finch & 2 & $100 \%$ \\
Blue Jay & 4 & $75 \%$ \\
Fish Crow & 9 & $55 \%$ \\
House Sparrow & 6 & $50 \%$ \\
Common Grackle & 6 & $33 \%$ \\
Total & 40 & $70 \%$ \\
\hline
\end{tabular}

in the United States and the low fatality rates in Hooded Crows in Egypt from the Egyptian strain of WNV (Egypt 1951) are likely attributable to genetic differences in the viral genotypes between the two strains (Brault et al. 2004).

American Crows died between days 4 and 8 post-inoculation and exhibited progressive clinical signs, starting on days 3-5 postinoculation, of lethargy, ataxia, unusual posture, inability to perch or stand, recumbency, and death (R. McLean unpubl. data). The infected American Crows were viremic, with high virus titers throughout the post-inoculation period, including during the first 3-4 days before they showed clinical signs of illness. Laboratory experiments have demonstrated multiple routes of transmission of WNV in avian species, but routes other than bites of infected mosquitoes have not been shown to occur in nature. Direct transmission between infected and uninfected contact American Crows and other species occurred during these experiments, and the clinical signs and fatality rates were similar between the contact-infected and needle-infected birds (McLean et al. 2001, N. Komar et al. 2003). The 15 American Crows in one study where direct transmission occurred were housed together in a free-flying arrangement with multiple roosts in a BSL-3 animal facility for six weeks prior to infection and had generally adjusted socially to each other so that pecking between birds had decreased greatly (R. McLean unpubl. data). Healthy American Crows did not pick on sick American Crows and tended to avoid them during later stages of clinical disease. The delay of 3-5 days in the onset of clinical disease in the contact American Crows (not inoculated with WNV) after clinical disease was occurring in inoculated American Crows suggests that transmission was likely by the oral route from the virus-laden exudates regularly excreted by clinically ill birds on roosts, floor, and around food and water containers (Komar et al. 2002). Oral transmission of WNV was demonstrated in five bird species, and American Crows became infected after ingesting the carcass of a WNV-infected House Sparrow (N. Komar et al. 2003) and WNV-infected white mice (R. McLean unpubl. data). It is not known whether direct contact or oral transmission occurs in nature, nor whether these methods of transmission would be important beyond the normal mosquito transmission 
route; however, it is likely that predatory birds are acquiring some WNV infections by eating infected birds and small mammals.

When animals died from WNV infection, it was assumed they were dead-end hosts for the virus and would not contribute to further virus transmission by infecting mosquitoes. However, corvids and many of the other 22 species infected in the laboratory circulated virus in their blood in sufficient titers to infect mosquitoes that would feed on them, and a number of these susceptible species had viremias of sufficient titers and duration to be considered competent reservoir hosts. Individuals of species that experienced mortality had very high viremias for 3-5 days before death and could thus contribute significantly to transmission (Table 6; N. Komar et al. 2003). Sick and viremic birds would also be a more receptive host for mosquito feeding and could contribute even more to local transmission than healthy birds. In addition, American Crows and other species shed WNV through oral and cloacal exudates at high titers for days; for some corvid species, the virus could be detected on oral and cloacal swabs for days after death (Komar et al. 2002). A rapid dip-stick test (VecTest) was found useful in testing dead corvids, particularly American Crows, and a few other species for WNV infection, and this simple test could be used for rapid field evaluation in surveillance programs, with results obtained in 15 min (Lindsay et al. 2003). However, the VecTest is not as useful with many other non-corvid species, which do not regularly excrete enough WNV virus to be detected by testing swabs; WNV can be detected in these birds by testing tissues (Stone et al. 2004).

Mortality from WNV infection among smaller bird species and nestling birds is poorly known and certainly underestimated. Warblers (15 species; Parulidae), chickadees (3 species; Paridae), and wrens (4 species; Troglodytidae) have all been reported WNV-positive (CDC 2005b), but few individual bird carcasses are found. Generally, nestlings are more susceptible than adults to mosquito-borne viral infections (Holden et al. 1973, McLean et al. 1989), as is true with WNV in American White Pelicans (Rocke et al. 2005). In addition, nestlings are more exposed and defenseless to infected mosquitoes; thus, mosquitoes more frequently and easily feed upon them (Blackmore and Dow 1958).

\section{Effect of West Nile Virus on Bird Populations}

The high fatality rates among susceptible bird species, especially American Crows, suggest that populations of some species may be suffering (R. McLean 2004). The only large-scale bird-population data available to determine whether WNV has affected bird populations are trend data from citizen monitoring surveys: Christmas Bird Count, Breeding Bird Survey, Project Feeder Watch, Great Backyard Bird Count, Neighborhood Nest Watch, and Bird Conservation Network.

The North American Breeding Bird Survey (BBS) is conducted by skilled participants from the United States and Canada each June to collect data on breeding birds along established roadside survey routes (Sauer et al. 2003). These counts may be the most useful in analyzing potential population effects of WNV mortality, because they produce year-to-year comparisons of the numbers of summer breeding birds where they are directly being exposed to WNV transmission. However, no detailed analyses of population trends at multiple routes or sites within WNV-affected regions or habitats have been conducted to evaluate possible WNVinduced declines. Examination of some historical BBS state-wide data for New York and New Jersey where WNV activity has been present for six years show that American Crow populations increased during the past several decades and were in record numbers prior to the invasion of WNV into the New York City area (Fig. 3; Sauer et al. 2003). This regional density of susceptible hosts may have contributed to the survival and establishment of the introduced virus. Since 2000, however a consistent sustained decline in population counts is evident in the state survey trend data for New York.

Christmas Bird Count (CBC) data is derived from counts of all birds found on a traditional site or route during one day within a two-week period around Christmas on $\sim 2,000$ sites or counts each year for $>100$ continuous years. However, the counts are made regardless of weather that could affect bird activity, and routes containing or missing winter roosts of communal bird species such as American Crows could bias the counts. Statistical and graphical analyses of CBC data for 10 bird species from six northeastern states through the 


\section{$\bullet-\mathrm{WI} \rightarrow \mathrm{NY} \rightarrow-\mathrm{NJ}$}

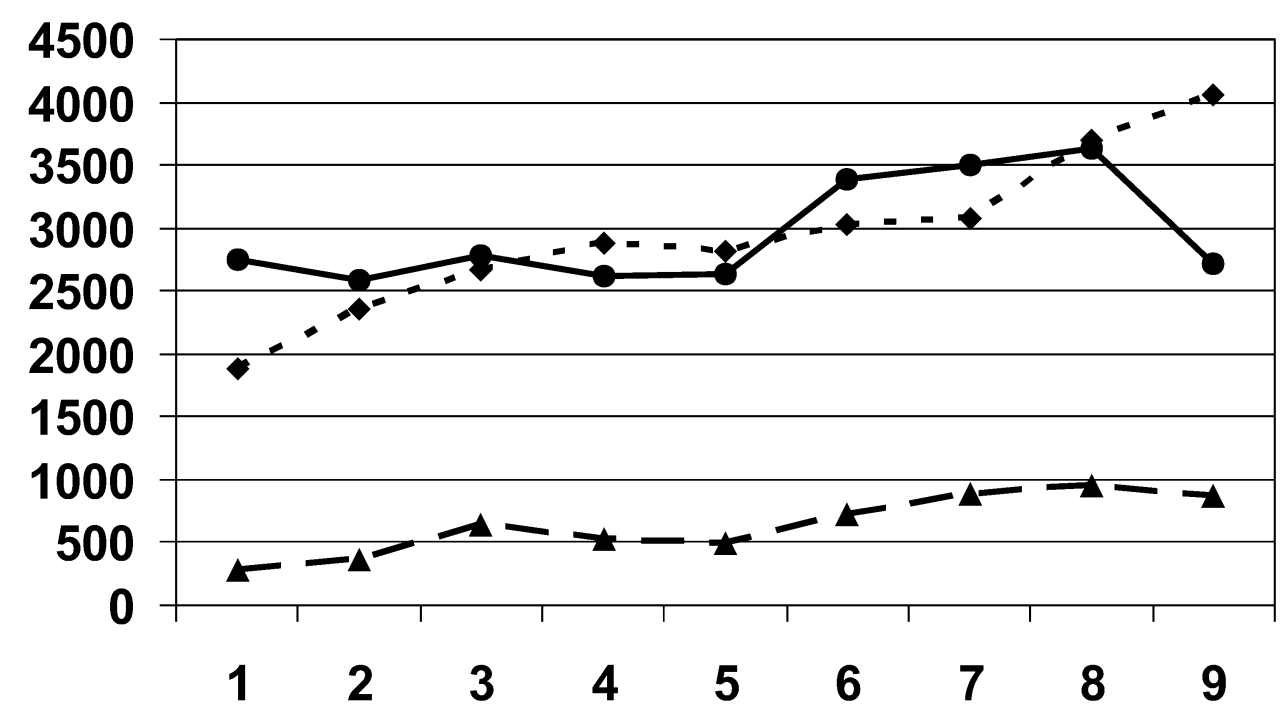

Fig. 3. Four-year mean transect counts from the Breeding Bird Survey for Wisconsin (WI), New Jersey (NJ), and New York (NY) from 1968 to 2003 (Sauer et al. 2003).

winter of 2003 could not determine whether WNV was responsible for any significant declines in bird populations, even when comparing counts in counties with and without WNV detected (Caffrey and Peterson 2003). The analyses found a weak association only for American Crows and Great Horned Owls (Bubo virginianus); however, the two data sets used for the analyses (CBC and presence or absence of WNV in a county) are too insensitive to detect anything but major population declines. Dead birds that test positive for WNV are reported by counties (USGS 2005), but counties differ in effort and duration of reporting beyond the first positive birds. Thus, county-level data do not reflect the true focal and patchy distribution of WNV activity, as was evident in Connecticut in 2000 (Beckwith et al. 2002). However, analysis of CBC data from the New York City area showed a local decline in the number of crows in the affected zone from 1998 to after the epizootic in 1999 (Eidson et al. 2001a). Crow populations in some localities there continued to decline by as much as $90 \%$, but adjacent areas to the east on Long Island showed no detectable declines (Chu et al. 2003).

Project FeederWatch (PFW) is a winter-long counting of birds in residential yards (for two consecutive days, every two weeks) throughout the United States and Canada (Wells et al. 1998). To determine whether any discernible declines in bird abundance occurred following intensive WNV transmission, PFW data from 800-1,400 sites for six species were conducted to determine whether there were unusual increases or declines in bird abundance between the winters of 2001-2002 and 2002-2003 (Bonter and Hochachka 2003). Some declines were observed in PFW data, and to confirm these declines, they were compared with CBC data from 28 geographically similar sites in upper Midwestern states where WNV activity was intense in summer 2002 (Campbell 2003, Ringia et al. 2004). The only notable declines were observed in chickadees, Tufted Titmice (Baeolophus bicolor), and American Crows; these were local declines with patchy regional distribution. No regional large-scale declines could be documented. The local declines were, however, synchronized over a broad area, and WNV was the suspected cause. Blue Jay, Northern Cardinal (Cardinalis cardinalis), and House Sparrow populations showed no declines during the same period.

The massive nestling losses of American White Pelicans in the north-central United States during 2002-2003 (see above) indicate 
that WNV could have a large effect on national American White Pelican populations through reduced recruitment. The $25 \%$ declines in survival in four populations of the Greater Sage-Grouse in 2003 (Walker et al. 2004) were followed by subsequent declines in attendance at the breeding leks the following spring at WNV-affected sites, threatening local populations. The broader implications of this increased mortality from WNV infections will be addressed through coordinated and intensified monitoring of Greater Sage-Grouse populations during the peak of WNV transmission.

In summary, information on the effects of WNV on bird populations is meager, because the spatial distribution and intensity of outbreaks of WNV in birds have not been fully quantified and WNV has been suspected but not confirmed as the cause of many outbreaks. The high mortality rates from WNV in some corvid and raptor species throughout the United States and Canada are known, as well as specific die-offs in Greater Sage-Grouse and American White Pelican, but the effects on wild bird populations are generally poorly documented. The national bird surveys are too imprecise to detect direct effects but may be useful for longterm trends in declines associated with WNV. Detailed and precise field studies are needed to measure actual effects of WNV on local and regional populations to determine real mortality rates and effects on population dynamics.

\section{Ecology and Management of West Nile Virus}

The primary transmission cycle of WNV involves the regular exchange of virus between mosquitoes, primarily in the genus Culex, and wild birds. The number and species of birds involved as hosts and the extent of their involvement depends on their susceptibility and reservoir competence as well as the epidemiological history and current pattern of virus transmission in a geographic region. More information needs to be gathered on natural infections in free-ranging species through field investigations testing for WNV antibody in healthy birds under varying epidemiological conditions. Antibody prevalences are estimates of exposure rates but do not provide information about the reservoir competence of species to infect mosquitoes nor their survival rate from infections. For example, the antibody prevalence in an Illinois American Crow population that experienced an epizootic from WNV was 3.2\% (5 of 156) following a $68 \%$ mortality rate (Yaremych et al. 2004), confirming the very low survival demonstrated in experimental studies (McLean et al. 2001). Other studies have found varying antibody prevalences in free-ranging birds (Table 7), not including American Crows, in New York City in 1999 (35\% of 430 birds; Komar et al. 2001a), New York City in 2000 (16.7\% of 353 birds; Komar et al. 2001b), Florida in 2001 (10.5\% of 152 birds; Godsey et al. 2005), and Illinois in 2002 (5.3\% of 1,784

TABLE 7. Antibody prevalence (\%) to West Nile virus (WNV) in bird species sampled during field investigations in the United States, 1999-2002 (1999: Komar et al. 2001a; 2000: Komar et al. 2001b; 2001: Godsey et al. 2005; 2002: Ringia et al. 2004).

\begin{tabular}{|c|c|c|c|c|}
\hline Species & $\begin{array}{c}\text { WNV } 1999 \\
\text { New York City }\end{array}$ & $\begin{array}{c}\text { WNV } 2000 \\
\text { New York City }\end{array}$ & $\begin{array}{l}\text { WNV } 2001 \\
\text { Florida }\end{array}$ & $\begin{array}{l}\text { WNV } 2002 \\
\text { Illinois }\end{array}$ \\
\hline House Sparrow & 69 & 9 & 11 & 11 \\
\hline Rock Pigeon ${ }^{a}$ & 15 & 55 & 4 & 55 \\
\hline Chicken $^{\mathrm{b}}$ & 57 & 6 & 16 & 8 \\
\hline Blue Jay & NS & 0 & NS & NS \\
\hline Northern Cardinal & NS & 69 & 75 & 12 \\
\hline American Robin ${ }^{c}$ & NS & NS & NS & 4 \\
\hline Gray Catbird & NS & 35 & NS & 8 \\
\hline Northern Mockingbird ${ }^{\mathrm{d}}$ & NS & NS & 50 & NS \\
\hline Mourning Dove $\mathrm{e}^{\mathrm{o}}$ & NS & NS & 0 & 9 \\
\hline Overall prevalence & 35 & 17 & 11 & 5 \\
\hline
\end{tabular}

${ }^{a}$ Columba livia.

${ }^{\mathrm{b}}$ Gallus gallus domesticus.

${ }^{c}$ Turdus migratorius.

${ }^{\mathrm{d}}$ Mimus polyglottos.

${ }^{\mathrm{e}}$ Zenaida macroura.

NS $=$ not sampled 
birds; Ringia et al. 2004), the highest antibody prevalences being in the Northern Cardinal, Rock Pigeon (Columba livia), House Sparrow, and Gray Catbird (Dumetella carolinensis). The transmission patterns and ecology of the introduced NY99 strain of WNV are unique when compared with other mosquito-borne viruses of birds in North America, such as SLE, EEE, and WEE viruses (McLean et al. 2001), and distinctly different from the ecology of historical strains of WNV circulating in the eastern hemisphere (McLean et al. 2002). The ecology of the NY99 strain has evolved during the past six years as the virus has moved into different habitats and ecosystems across North America. Epizootics in local birds occurred when WNV entered new areas with naïve and susceptible bird and mosquito populations (Bernard et al. 2001, Pape 2004, Kramer 2005). The dynamics of transmission among the various competent mosquito vectors (Turell et al. 2001, Apperson et al. 2004) with the variety of reservoir-competent and -incompetent susceptible avian hosts are complex and vary regionally. In some of these new habitats, WNV caused mortality among some unexpected vertebrate hosts (reptiles, marine mammals, and large ungulates; CDC 2005). The traditional mosquito-bird transmission cycle may have changed as additional, nonvectored routes of transmission (direct transmission between birds and transmission by ingestion of infected prey) were identified in laboratory studies (McLean et al. 2001, N. Komar et al. 2003). Potential secondary transmission cycles involving reptiles and mammals and alternate vectors appear possible as well (Fig. 4). There is speculation that host diversity could affect WNV transmission. Recent analysis of avian biodiversity and WNV activity in Florida indicate an inverse relationship between diversity of nonpasserine species and WNV transmission because of a dilution effect (Ezenwa et al. 2005). Infected mosquitoes feed more frequently on reservoir-incompetent avian species, creating dead ends for the virus. This biodiversity dilution effect could influence WNV transmission in the tropics, where bird diversity is much greater than in temperate climates in North America.

There are many biological factors associated with vectors, hosts, and virus that influence the occurrence and frequency of transmission, as well as many abiotic factors, including temperature, moisture, and landscape characteristics that affect the functioning of the biological factors (McLean 1991). Because of these dynamic factors, the ecology of WNV will not be the same in different regions and habitats of North America. There are major regional differences in transmission patterns, as evidenced by the

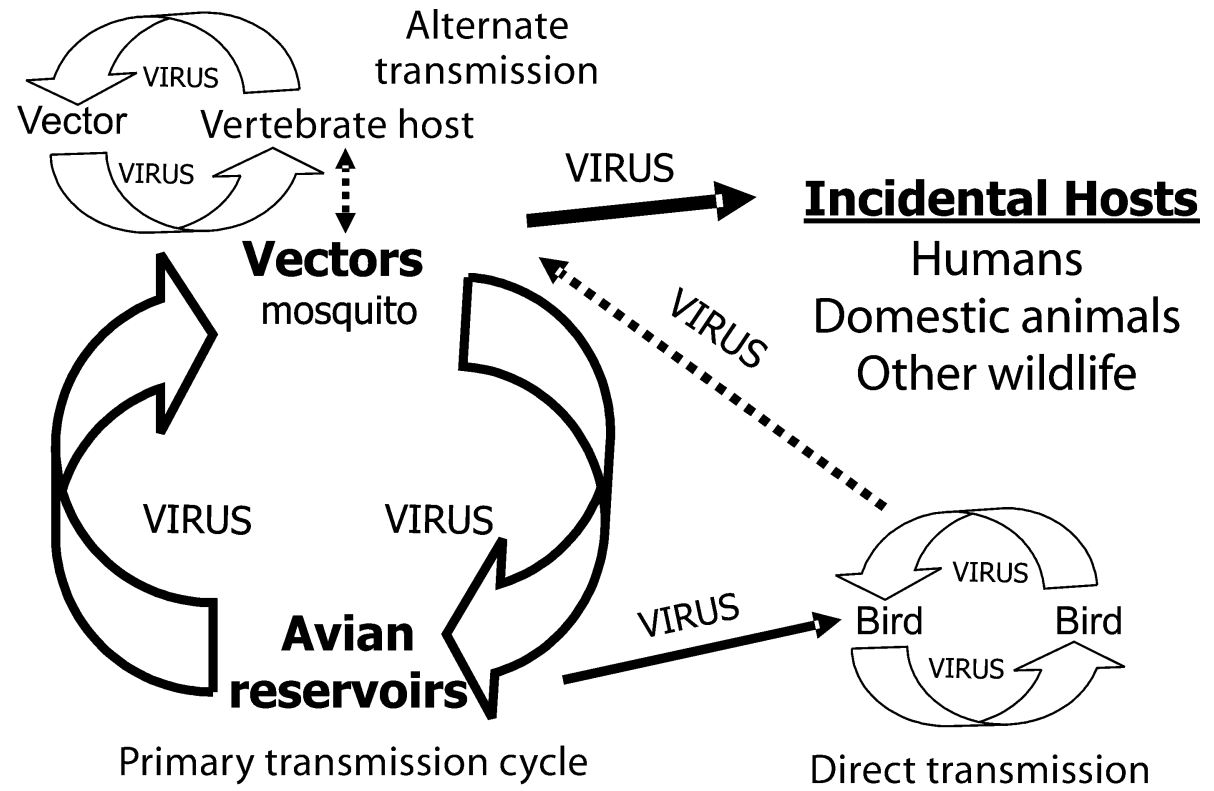

FIG. 4. Transmission cycle for West Nile virus in North America. 
increase in the infection rate in American Crows during the summer transmission season in Connecticut, where the WNV infection rate peaked during September 2000, at a remarkable 98\% (Beckwith et al. 2002); whereas, in central Texas (Harris County), the infection rate in dead birds peaked in August at 50\% (Tesh et al. 2004).

Climate and seasonal weather affect the winter survival, spring initiation, summer intensity and diversity, and the intensity and distribution of local or regional mosquito-borne virus activity. Climate appears to have less effect on winter survival and early-spring initiation of WNV than of other mosquito-borne viruses, such as SLE in North America, because WNV-positive dead birds appear in early April in northern temperate climates before the virus could have been reintroduced from the south by migratory birds (CDC 2002b). This local survival of WNV in temperate climates in infected hibernating adult Culex mosquitoes (Nasci et al. 2001) or in other vector or vertebrate host species, as well as the year-round transmission in southern states, makes it unique among flaviviruses and facilitates the establishment of semipermanent to permanent foci of WNV activity. Transmission of WNV seems to be sustained at low rates even under suboptimum conditions (e.g. in the eastern United States in 2004, as indicated by the broad distribution of WNV activity in 46 of 48 continental states [CDC 2004]). Summer amplification dramatically increases when all the crucial factors are synchronized and favorable for virus transmission, but these complex interactions are difficult to predict. However, some weather patterns (e.g. wet springs followed by hot, dry summers) seem to be associated with more-intense virus activity.

Weather conditions in New York City in 1999 during the initial introduction (Petersen and Roehrig 2001), and in Colorado (Pape 2004) and neighboring states in 2003, matched conditions that favor virus transmission through increased mosquito production, shortened generation cycles in mosquitoes, more rapid virus replication in infected adult mosquitoes, earlier and more successful early broods of some avian species, and concentration of mosquito vectors and susceptible avian hosts together, particularly in urban or suburban habitats where the avianfeeding Culex mosquitoes breed in containers in higher densities (Epstein and Defillipo
2001). The weather pattern in the United States in 2004 was the opposite of that in 2003, with the second-coldest summer and second-highest mean precipitation of the past 20 years (National Oceanic Atmospheric Administration 2005), which may help explain the reduced intensity of WNV transmission in 2004 (Smith 2005).

Early-spring virus transmission between mosquitoes and birds starts the amplification cycle sooner and allows it to expand to a much greater extent under these optimum conditions, and results in epizootics or epidemics in associated animal and human populations. The intensity of local transmission and the size of the epizootics in birds subsequently influence the extent of local spreading and the seasonal infection of migratory birds that disseminate WNV over long distances. The high virulence of the NY99 strain of WNV aided its rapid establishment and dissemination throughout North America by infecting a very large number of bird species and a broad range of other vertebrate species, producing high viremias in many bird species. This allows infection of a wide variety and number of mosquito vector species, facilitating the ease and high intensity of transmission, establishing primary and secondary transmission cycles, and allowing direct contact and oral transmission between birds, and likely assists in the survival of the virus under extreme environmental conditions. However, the virulence also caused high mortality rates in birds and mortality in mammals and reptiles. A large number of bird species are naturally exposed to WNV, and many of these are reservoir-competent and have sufficient viremias to be infectious to vector mosquitoes (Komar et al. 2003). The density, habits, breeding activity, local movement, and association with vector mosquitoes are important features of these species that help determine their contribution to local transmission of WNV. The residency status of birds in a locality also affects their participation in local virus transmission (Crans et al. 1994). Some bird species move the virus long distances during migration while they are viremic and can introduce the virus to new locations. The distance and efficiency by which WNV can be spread depends on the particular species; some species are viremic for three to five days and travel hundreds of kilometers per day during migration, carrying the virus $800-1,500 \mathrm{~km}$ while they are still infectious to new susceptible 
mosquitoes. Modeling of various scenarios of the WNV spread across the continent concluded that the observed patterns of spread were best explained by migratory birds serving as longdistance transport agents (Peterson et al. 2003). The species likely involved in moving WNV are those that are reservoir-competent, with high viremias of long duration, and do not suffer clinical disease. Evidence is being collected from field studies that may identify some of the important migratory species (Ringia et al. 2004, R. McLean et al. unpubl. data).

All these new features of WNV present some uncertainties in understanding the ecology of this virus and new challenges for the management of the disease. Prevention and management of mosquito-borne viruses in free-ranging birds will be extremely difficult to control through interruption of transmission because of the close interaction between wild birds and mosquitoes in shared habitats. Integrated pest management is the best control strategy, and specific control to limit mosquito population growth by targeting larval production sites with antilarval products (biological and chemical) and through habitat modification are the most viable options (Moore et al. 1993, McLean et al. 2002). Insecticidal control of adult infected mosquitoes will be too late in the season to modify transmission among birds, though it has been used with limited success to reduce risks to humans (CDC 2000).

Use of vaccines to prevent infections in animals and humans and to minimize or control epizootics has a long history with some of the bird-associated viruses that affect domestic animals (Monath 2001). Prevention through use of WNV vaccines has been investigated in some species of birds with mixed success. A WNV killed-virus vaccine licensed for equines was evaluated in American Crows with limited success $(40 \%$ of vaccinated American Crows survived WNV challenge; R. McLean unpubl. data), and this vaccine was also used in an effort to protect valuable birds in zoological collections from infection and mortality in the United States. An experimental DNA-based WNV vaccine was evaluated in Fish Crows with partial success; all the birds vaccinated by injection survived, but only $50 \%$ of birds given the vaccine orally survived (Turell et al. 2003). This same DNA vaccine is being evaluated in the California Condor (Gymnogyps californianus) and Red-tailed Hawk (Buteo jamaicensis) (Redig
2005). New vaccines and the development of vaccine delivery methods are being investigated to improve vaccination success in birds.

\section{Conclusion}

The rapid spread of WNV throughout North America and into countries in the Caribbean and Central and South America, and the rapid increase in infection and mortality rates in birds during the past six years, indicate the emergence of an invasive and epizootic disease of major importance to North American birds (McLean 2002). The virus has infected a broad range of vertebrate host species and caused mortality in many of these species, and may be affecting populations of some avian species in North America. The extent of mortality in regional and national bird populations and the overall significance and effects are unknown, but recent evidence suggests that there are some significant local effects and possible long-term effects. Consequences to ecosystems of the significant reduction in populations of some avian species (e.g. corvids) that are replaced by other, competing species will not be known for years. These issues need to be addressed seriously by wildlife agencies soon, because mortality rates from this one disease in some bird populations are much greater than the normal compensatory mortality and will be affecting recruitment and suppressing populations. To combat this exotic disease in North America, collaborative efforts between scientists and research groups will be required to learn more about the disease ecology of WNV, including host susceptibility, reservoir competence, and interactions between hosts, mosquitoes, environmental factors, and disease (Marra et al. 2004).

\section{Literature Cited}

Apperson, C. S., H. K. Hassan, B. A. Harrison, H. M. Savage, S. E. Aspen, A. Farajollahi, W. Crans, T. J. Daniels, R. C. Falco, M. Benedict, AND OTHERs. 2004. Host feeding patterns of established and potential mosquito vectors of West Nile virus in the eastern United States. Vector-Borne and Zoonotic Diseases 4:71-82.

Beckwith, W. H., S. Sirpenski, R. A. French, R. Nelson, ANd D. Mayo. 2002. Isolation of eastern equine encephalitis virus and West Nile virus from crows during increased arbovirus surveillance in Connecticut, 2000. American 
Journal of Tropical Medicine and Hygiene 66: $422-426$.

Bernard, K. A., J. G. Maffei, S. A. Jones, E. B. Kauffman, G. D. Ebel, A. P. Dupuis II, K. A. Ngo, D. C. Nicholas, D. M. Young, P.-Y. ShI, AND OTHERs. 2001. West Nile virus infection in birds and mosquitoes, New York State, 2000. Emerging Infectious Diseases 7:679-685.

Blackmore, C. G. M., L. M. Stark, W. C. Jeter, R. L. Oliveri, R. G. Brooks, L. A. Conti, and S. T. Wiersma. 2003. Surveillance results from the first West Nile virus transmission season in Florida, 2001. American Journal of Tropical Medicine and Hygiene 69:141-150.

Blackmore, J. S., AND R. P. Dow. 1958. Differential feeding of Culex tarsalis on nestling and adult birds. Mosquito News 18:15-17.

Blitvich, B. J., I. Fernandez-Salas, J. F. ContrerasCordero, N. L. Marlenee, J. I. Gonzalez-Rojas, N. Komar, D. J. Gubler, C. H. Calisher, and B. J. Beaty. 2003. Serologic evidence of West Nile virus infection in horses, Coahuila State, Mexico. Emerging Infectious Diseases 9:853-856.

Bonter, D. N., and W. M. НоchachKa. 2003. Declines of chickadees and corvids: Possible impacts of West Nile virus. American Birds: The 103rd Christmas Bird Count 2002-2003:22-25.

Brault, A. C., S. A. Langevin, R. A. Bowen, N. A. Panella, B. J. Biggerstaff, B. R. Miller, and N. Komar. 2004. Differential virulence of West Nile strains for American Crows. Emerging Infectious Diseases 10:2161-2168.

Caffrey, C., and C. C. Peterson. 2003. West Nile virus may not be a conservation issue in northeastern United States. American Birds: The 103rd Christmas Bird Count 2002-2003: 14-21.

Caffrey, C., S. C. R. Smith, and T. J. Weston. 2005. West Nile virus devastates an American Crow population. Condor 107:128-132.

Caffrey, C., T. J. Weston, and S. C. R. Smith. 2003. High mortality among marked crows subsequent to the arrival of West Nile virus. Wildlife Society Bulletin 31:870-872.

California Department of Health Services. 2005. West Nile Virus in California in 2005. California West Nile Virus website. [Online.] Available at http://westnile.ca.gov.

Campbell, R. 2003. Summary of West Nile virus activity, United States 2002. Fourth National Conference on West Nile Virus in the United States. Centers for Disease Control and Prevention. [Online.] Available at www.cdc.gov/ncidod/dvbid/westnile/conf/ February_2003.htm

Centers for Disease Control and Prevention. 1999. Outbreak of West Nile-like viral encephalitis-New York, 1999. Morbidity and Mortality Weekly Report 48:845-849.
Centers for Disease Control and Prevention. 2000. Guidelines for surveillance, prevention, and control of West Nile virus infectionUnited States. Morbidity and Mortality Weekly Report 49:25-28.

Centers for Disease Control and Prevention. 2001. West Nile virus activity - Eastern United States, 2001. Morbidity and Mortality Weekly Report 50:617-619

Centers for Disease Control and Prevention. 2002a. West Nile virus activity - United States, August 8-14, 2002, and Louisiana, January 1-August 7, 2002. Morbidity and Mortality Weekly Report 51:681-683.

Centers for Disease Control and Prevention. 2002b. West Nile virus activity - United States. 2001. Morbidity and Mortality Weekly Report 51:497-501.

Centers for Disease Control and Prevention. 2004. West Nile virus activity-United States, November 9-16, 2004. Morbidity and Mortality Weekly Report 53:1071-1072.

Centers for Disease Control and Prevention. 2005a. West Nile virus activity - United States, 2005. Morbidity and Mortality Weekly Report 54:1133-1134.

Centers for Disease Control and Prevention. 2005b. West Nile virus. [Online.] Available at www.cdc.gov/ncidod/dvbid/westnile/bird species.htm.

Chu, M., W. Stone, K. J. McGowan, A. A. Dhondt, W. M. HochachKa, and J. E. Therrien. 2003. West Nile file. Birdscope (Winter):10-11.

Crans, W. J., D. F. Caccamise, and J. R. McNelly. 1994. Eastern equine encephalomyelitis virus in relation to the avian community of a coastal cedar swamp. Journal of Medical Entomology 31:711-728.

Dupuis, A. P., III, P. P. Marra, and L. D. Kramer. 2003. Serologic evidence of West Nile virus transmission, Jamaica, West Indies. Emerging Infectious Diseases 9:860-863.

Eidson, M., N. Komar, F. Sorhage, R. Nelson, T. Talbot, F. Mostashari, R. McLean, and West Nile Virus Avian Mortality Surveillance Group. 2001a. Crow deaths as a sentinel surveillance system for West Nile virus in the north-eastern United States, 1999. Emerging Infectious Diseases 7:615-620.

Eidson, M., L. Kramer, W. Stone, Y. Hagiwara, K. Schmit, and West Nile Virus Avian Mortality Surveillance Group. 2001b. Dead bird surveillance as an early warning system for West Nile virus. Emerging Infectious Diseases 7:631-635.

Epstein, P. R., and C. Defillipo. 2001. West Nile virus and drought. Global Change and Human Health 2:2-4. 
Estrada-Franco, J. G., R. Navarro-Lopez, D. W. C. Beasley, L. Coffey, A. S. Carrara, A. Travassos da Rosa, T. Clements, E. Wang, G. V. Ludwig, A. C. Cortes, and others. 2003. West Nile virus in Mexico: Evidence of widespread circulation since July 2002. Emerging Infectious Diseases 9:1604-1607.

Ezenwa, V. O., M. S. Godsey, R. J. King, and S. C. Guptill. 2005. Avian diversity and West Nile virus: Testing associations between biodiversity and infectious disease risk. Proceedings of the Royal Society of London, Series B 273:109-117.

Gancz, A. Y., I. K. Barker, R. Lindsay, A. Dibernardo, K. McKeever, and B. Hunter. 2004. West Nile virus outbreak in North American owls, Ontario, 2002. Emerging Infectious Diseases 10:2135-2142.

Godsey, M. S., Jr., M. S. Blackmore, N. A. Panella, K. Burkhalter, K. Gottfried, L. A. Halsey, R. Rutledge, S. A. Langevin, R. Gates, K. M. LAMONTE, AND Others. 2005. West Nile virus epizootiology in the southeastern United States, 2001. Vector-Borne and Zoonotic Diseases 5:82-89.

Guptill, S. C., K. G. Julian, G. L. Campbell, S. D. Price, and A. A. Marfin. 2003. Early-season avian deaths from West Nile virus as warnings of human infection. Emerging Infectious Diseases 9:483-484.

Hadler, J., R. Nelson, T. McCarthy, T. Andreadis, M. J. Lis, R. French, W. Beckwith, D. Mayo, G. Archambault, and M. Carter. 2001. West Nile virus surveillance in Connecticut in 2000: An intense epizootic without high risk for severe human disease. Emerging Infectious Diseases 7:636-642.

Hayes, N. 2004. Summary of West Nile virus activity, United States 2003. Fifth National Conference on West Nile virus in the United States. Centers for Disease Control and Prevention. [Online.] Available at www.cdc.gov/ncidod/ dvbid/westnile/conf/index.htm.

Health Canada. 2005. West Nile Virus Surveillance Information. [Online.] Available at www.phacaspc.gc.ca/wnv-vwn/index.html.

Holden, P., D. B. Francy, C. J. Mitchell, R. O. Hayes, J. S. Lazuick, and T. B. Hughes. 1973. House Sparrows, Passer domesticus (L.), as hosts of arboviruses in Hale County, Texas. II. Laboratory studies with western equine encephalitis virus. American Journal of Tropical Medicine and Hygiene 22:254-262.

Jozan, M., R. Evans, R. McLean, R. Hall, B. Tangredi, L. Reed, and J. Scott. 2003. Detection of West Nile virus infection in birds in the United States by blocking ELISA and immunohistochemistry. Vector-Borne and Zoonotic Diseases 3:99-110.
Komar, N., J. Burns, C. Dean, N. A. Panella, S. Dusza, AND B. Cherry. 2001b. Serologic evidence for West Nile virus infection in birds in Staten Island, New York, after an outbreak in 2000. Vector-Borne and Zoonotic Diseases 1:191-196.

Komar, N., R. Lanciotti, R. Bowen, S. Langevin, And M. Bunting. 2002. Detection of West Nile virus in oral and cloacal swabs collected from bird carcasses. Emerging Infectious Diseases 8: 741-742.

Komar, N., S. Langevin, S. Hinten, N. Nemeth, E. Edwards, D. Hettler, B. Davis, R. Bowen, And M. Bunting. 2003. Experimental infection of North American birds with the New York 1999 strain of West Nile virus. Emerging Infectious Diseases 9:311-323.

Komar, N., N. A. Panella, J. E. Burns, S. W. Dusza, T. M. Mascarenhas, and T. O. Talbot. 2001a. Serologic evidence for West Nile virus infection in birds in the New York City vicinity during an outbreak in 1999. Emerging Infectious Diseases 7:621-625.

Komar, O., M. B. Robbins, K. Klenk, B. J. Blitvich, N. L. Marlenee, K. L. Burkhalter, D. J. Gubler, G. Gonzalvez, C. J. Pena, A. T. Peterson, and OTHERs. 2003. West Nile virus transmission in resident birds, Dominican Republic. Emerging Infectious Diseases 9:1299-1302.

Kramer, V. 2005. West Nile virus activity in California in 2004. Sixth National Conference on West Nile virus in the United States. Centers for Disease Control and Prevention. [Online.] Available at www.cdc.gov/ncidod/ dvbid/westnile/conf/index.htm.

Lanciotti, R. S., J. T. Roehrig, V. Deubel, J. Smith, M. Parker, K. Steele, B.Crise, K. E. Volpe, M. B. Crabtree, J. H. Scherret, and others. 1999. Origin of the West Nile virus responsible for an outbreak of encephalitis in the Northeastern United States. Science 286:2333-2337.

Levy, C. 2005. West Nile virus in Arizona. Sixth National Conference on West Nile virus in the United States. Centers for Disease Control and Prevention. [Online.] Available at www.cdc.gov/ ncidod/dvbid/westnile/conf/index.htm.

Lindsay, R., I. Barker, G. Nayar, M. Drebot, S. Calvin, C. Scammell, C. Sachvie, T. ScammellLa Fleur, A. Dibernardo, M. Andonova, and OTHERS. 2003. Rapid antigen-capture assay to detect West Nile virus in dead corvids. Emerging Infectious Diseases 9:1406-1410.

Ludwig, G. V., P. P. Calle, J. A. Mangiafico, B. L. Raphael, D. K. Danner, J. A. Hile, T. L. Clippinger, J. F. Smith, R. A. Cook, And T. McNamara. 2002. An outbreak of West Nile virus in a New York City captive wildlife population. American Journal of Tropical Medicine and Hygiene 67:67-75. 
Malkinson, M., and C. Banet. 2002a. The role of birds in the ecology of West Nile virus in Europe and Africa. Pages 309-322 in Japanese Encephalitis and West Nile Viruses (J. S. Mackenzie, A. D. T. Barrett, and V. Deubel, Eds.). Springer-Verlag, Berlin.

Malkinson, M., C. Banet, Y. Weisman, S. Pokamonski, R. King, M. T. Drouet, and V. Deubel. 2002b. Introduction of West Nile virus in the Middle East by migrating White Storks. Emerging Infectious Diseases 8:392-397.

Marfin, A. A., L. R. Petersen, M. Eidson, J. Miller, J. Hadler, C. Farello, B. Werner, G. L. Campbell, M. Layton, P. Smith, and the Arbonet Cooperative Surveillance Group. 2001. Widespread West Nile virus activity, eastern United States, 2000. Emerging Infectious Diseases 7:730-735.

Marra, P. P., S. Griffing, C. Caffrey, A. M. Kilpatrick, R. McLean, C. Brand, E. Saito, A. P. Dupuis, L. Kramer, and R. NovaK. 2004. West Nile virus and wildlife. BioScience 54: 393-402.

Mattar, S., E. Edwards, J. Laguado, M. Gonzalez, J. Alvarez, and N. Komar. 2005. West Nile virus antibodies in Columbian horses. Emerging Infectious Diseases 11:1497-1498.

McLean, R. G. 1991. Arboviruses of wild birds and mammals. Bulletin of the Society for Vector Ecology 16:3-16.

McLean, R. G. 2002. West Nile virus. A threat to North American avian species. Transactions 67th North American Wildlife and Natural Resource Conference:62-74.

McLean, R. G. 2004. West Nile virus: Impact on crow populations in the United States. Pages 180-184 in Proceedings 21st Vertebrate Pest Conference (R. M. Timm and W. P. Gorenzel, Eds.). University of California, Davis.

McLean, R. G., R. B. Shriner, L. J. Kirk, and D. J. Muth. 1989. Western equine encephalitis in avian populations in North Dakota, 1975. Journal of Wildlife Diseases 25:481-489.

McLean, R., S. R. Ubico, D. Bourne, and N. Komar. 2002. West Nile virus in livestock and wildlife. Current Topics in Microbiology and Immunology 267:271-308.

McLean, R. G., S. R. Ubico, D. E. Docherty, W. R. Hansen, L. Sileo, and T. S. McNamara. 2001. West Nile virus transmission and ecology in birds. Annals of the New York Academy of Science 951:54-57.

Mendez-Galvan, J. F. 2004. West Nile virus in Latin America. Fifth National Conference on West Nile virus in the United States. Centers for Disease Control and Prevention. [Online.] Available at www.cdc.gov/ncidod/dvbid/ westnile/conf/index.htm.
Monath, T. P. 2001. Prospects for the development of a vaccine against the West Nile virus. Annals of the New York Academy of Science 951:1-12.

Moore, C. G., R. G. McLean, C. J. Mitchell, R. S. Nasci, T. F. Tsai, C. H. Calisher, A. A. Marfin, P. S. Moore, and D. J. Gubler. 1993. Guidelines for arbovirus surveillance in the United States. U.S. Department of Health and Human Services, Public Health Service, CDC, NCID, DVBID, Fort Collins, Colorado.

Murgue, B., H. Zeller, and V. Deubel. 2002. The ecology and epidemiology of West Nile virus in Africa, Europe, and Asia. Current Topics in Microbiology and Immunology 267:195-221.

Nasci, R. S., H. M. Savage, D. J. White, J. R. Miller, B. C. Cropp, M. S. Godsey, A. J. Kerst, P. Bennett, K. Gottfried, and R. S. Lanciotti. 2001. West Nile virus in overwintering Culex mosquitoes, New York City, 2000. Emerging Infectious Diseases 7:742-744.

National Oceanic Atmospheric Administration. 2005. National Climatic Data Center, Asheville, North Carolina. [Online.] Available at lwf.ncdc.noaa.gov/oa/climate/research/cag3/ cag3.html.

Naugle, D. E., C. L. Aldridge, B. L. Walker, T. E. Cornish, B. J. Moynahan, M. J. Holloran, K. Brown, G. D. Johnson, E. T. Schmidtmann, R. T. Mayer, and others. 2004. West Nile virus: Pending crisis for Greater Sage-Grouse. Ecology Letters 7:704-713.

O'Leary, D. R., A. A. Marfin, S. P. Montgomery, A. M. Kipp, J. A. Lehman, B. J. Biggerstaff, V. L. Elko, P. D. Collins, J. E. Jones, and G. L. Campbell. 2004. The epidemic of West Nile virus in the United States, 2002. Vector-Borne and Zoonotic Diseases 4:61-70.

PAPE, J. 2004. West Nile virus in Colorado, 2003. Fifth National Conference on West Nile virus in the United States. Centers for Disease Control and Prevention. [Online.] Available at www.cdc.gov/ncidod/dvbid/westnile/conf/ index.htm.

Petersen, L. R., and J. T. Roehrig. 2001. West Nile virus: A reemerging global pathogen. Emerging Infectious Diseases 7:611-614.

Peterson, A. T., D. A. Vieglais, and J. K. Andreasen. 2003. Migratory birds modeled as critical transport agents for West Nile virus in North America. Vector-Borne and Zoonotic Diseases 3:27-37.

Redig, P. T. 2005. Wildlife population impacts of West Nile virus and progress on an avian vaccine. Sixth National Conference on West Nile virus in the United States. Centers for Disease Control and Prevention. [Online.] Available at www.cdc.gov/ncidod/dvbid/ westnile/conf/index.htm. 
Ringia, A. M., B. J. Blitvich, H.-Y. Koo, M. Van de Wyngaerde, J. D. Brawn, and R. J. NovaK. 2004. Antibody prevalence of West Nile virus in birds, Illinois, 2002. Emerging Infectious Diseases 10:1120-1124.

Rocke, T., K. Converse, C. Meteyer, and R. McLean. 2005. The impact of disease in American White Pelicans in North America. Waterbirds 28:87-94.

Sauer, J. R., J. E. Hines, and J. Fallon. 2003. The North American Breeding Bird Survey, Results and Analysis 1966-2002, version 2003.1. U.S. Geological Survey, Patuxent Wildlife Research Center, Laurel, Maryland.

Shaman, J., AND J. F. Day. 2005. Achieving operational hydrologic monitoring of mosquitoborne disease. Emerging Infectious Diseases 11:1343-1350.

Sмiтh, T. 2005. National West Nile virus surveillance summary, United States, 2004. Sixth National Conference on West Nile virus in the United States. Centers for Disease Control and Prevention. [Online.] Available at www.cdc.gov/ncidod/dvbid/westnile/conf/ index.htm.

Smithburn, K. C., T. P. Hughes, A. W. Burke, ANd J. H. PAul. 1940. A neurotropic virus isolated from the blood of a native of Uganda. American Journal of Tropical Medicine and Hygiene 20:471-492.

Steele, K. E., M. J. Linn, R. J. Schoepp, N. Komar, T. W. Geisbert, R. M. Manduca, P. P. Calle, B. L. Raphael, T. L. Clippinger, T. Larsen, AND OTHERs. 2000. Pathology of fatal West Nile virus infections in native and exotic birds during the 1999 outbreak in New York City, New York. Veterinary Pathology 37:208-224.

Stone, W. D., J. C. Okoniewski, J. E. Therrien, L. D. Kramer, E. B. Kauffman, and M. Eidson. 2004. VecTest as a diagnostic and surveillance tool for West Nile virus in dead birds. Emerging Infectious Diseases 10:2175-2181.

Swayne, D. E., J. R. Beck, C. S. Smith, W.-J. Shieh, AND S. R. ZAKI. 2001. Fatal encephalitis and myocarditis in young domestic geese (Anser anser domesticus) caused by West Nile virus. Emerging Infectious Diseases 7:751-753.
Tesh, R. B., R. Parsons, M. Silrin, Y. Randle, C. Sargent, H. Guzman, T. Wuithiranyagool, S. Higgs, D. L. Vanlandingham, A. A. Bala, And others. 2004. Year-round West Nile virus activity, Gulf Coast region, Texas and Louisiana. Emerging Infectious Diseases 10:1649-1652.

Turell, M. J., M. Bunning, G. V. Ludwig, B. Ortman, J. Chang, T. Speaker, A. Spielman, R. McLean, N. Komar, R. Gates, and OthERs. 2003. DNA vaccine for West Nile virus infection in Fish Crows (Corvus ossifragus). Emerging Infectious Diseases 9:1077-1081.

Turell, M. J., M. L. O'Guinn, D. J. Dohm, and J. W. Jones. 2001. Vector competence of North American mosquitoes (Diptera: Culicidae) for West Nile virus. Journal of Medical Entomology 38:130-134.

U.S. Geological Survey. 2005. West Nile virus maps. [Online.] Available at westnilemaps.usgs.gov/.

Walker, B. L., D. E. Naugle, K. E. Doherty, and T. E. Cornish. 2004. From the field: Outbreak of West Nile virus in Greater Sage-Grouse and guidelines for monitoring, handling, and submitting dead birds. Wildlife Society Bulletin 32:1000-1006.

Wells, J. V., K. V. Rosenberg, E. H. Dunn, D. L. Tessaglia-Hymes, and A. A. Dhondt. 1998. Feeder counts as indicators of spatial and temporal variation in winter abundance of resident birds. Journal of Field Ornithology 69:577-586.

Work, T. H., H. S. Hurlbut, and R. M. Taylor. 1955. Indigenous wild birds of the Nile Delta as potential West Nile virus circulating reservoirs. American Journal of Tropical Medicine and Hygiene 4:872-888.

Yaremych, S. A., J. M. Levengood, R. J. Novak, P. C. Mankin, and R. E. Warner. 2004. Gender determination and lack of sex-specific West Nile virus mortality in American Crows. Wildlife Society Bulletin 32:893-899.

Yaremych, S. A., R. E. Warner, P. C. Mankin, J. D. Brawn, A. Raim, and R. Novak. 2003. West Nile virus causes high mortality in a free-ranging population of American Crows (Corvus brachyrhynchos). Emerging Infectious Diseases 10:709-711. 